\title{
The Relationship Between Motivation and Job Satisfaction Among Teachers of Public Schools in Mafraq Province of Jordan
}

\author{
Dr. Nour Khaled Mashaqbah \\ Department of Educational Administration - \\ Faculty of Education, University of Hail, KSA
}

Doi:10.19044/esj.2018.v14n31p224 URL:http://dx.doi.org/10.19044/esj.2018.v14n31p224

\begin{abstract}
This study aimed at identifying the relationship between motivation and job satisfaction among teachers of public schools in Mafraq Province of Jordan. In order to do so, primary data were collected using self-completed questionnaires that were collected from (1260) public schools teachers, statistical analysis were used to analyze the relationships. The research has shown that: the degree of motivation among teachers of public schools in Mafraq Province is medium, as well as the degree of job satisfaction; and the research also showed that there is a statistically significant relationship between motivation and job satisfaction among teachers. The study showed that there is a lack of material incentives and bonuses, lack of a clear system of motivation that really measure the performance of the teachers, and lack of involvement of the teacher in decision-making. The results of this study suggest that in order to achieve a high and distinguished performance among the teachers, educational officials should consider working on the development of the laws, regulations and instructions of the system of bonuses and rewards commensurate with the requirements of the basic standard of living of the employees.
\end{abstract}

Keywords: Motivation, job satisfaction, teachers of public schools, education.

\section{Introduction}

A successful organization cannot separate its objectives from job satisfaction of its employees; the human elements are the main driver of any work in the organization, they achieve the goals of the organization by performing the duties assigned to each individual to the fullest. Therefore, the organization that willing to maintain its success and continuity should include a degree of job satisfaction of its employees within its development plans, by providing various incentives to maintain a good degree of satisfaction for the 
employees and this helps the continuity of the organization and its survival. At the end of the last century a serious scientific studies were made for the best working conditions that can be provided to enable employees to reach the highest level of work, and attention was also paid to the comfort of the individual in his work, materially and morally (Maqbol, 2003). There is a direct correlation relationship between the application of material and moral incentives and job satisfaction for the work environment (Awadallah, 2011). These incentives increase the desire to work, driving the behavior of workers in the direction that achieves the organization's goals (Raslan, 1978).

As the modern organizations have taken care of the job satisfaction of their employees so as the educational sector did, making the satisfaction of their employees one of its priorities, one of the most important pillars of the educational institution is the process of comprehensive development through education, were the success of the education process depends on the teacher who is the basis of the educational process were his performance directly effects the degree of success and progress of the educational process, the degree of satisfaction is reflected in the degree of his work and performance, which directly affects the ability, level and achievement of the students (Youseef, 1997). Thus, the importance of providing the appropriate psychological climate for individuals working in the education sector to reach educational outputs and good knowledge of the school work was emphasized. Job satisfaction is one of the main factors for the individual to be more adaptive to his environment (Alabiad, 2015).

The teacher is considered one of the cornerstones in the educational process, thus, the subject of achieving job satisfaction has become one of the topics that the behavioral and management scientists focusing on, they are interested in identifying the sources of job satisfaction for teachers and measuring the degree of their job satisfaction. Research the reasons that lead to job dissatisfaction because they reflect the performance of the work and the performance of his duties in the best required manner (Hamdi, 2011). Researchers have different views on the nature of the factors that affect job satisfaction, because of the different tendencies of individuals and their multiplicity, some see that the aspects and components of job satisfaction are in the content and conditions of the organizational work only (Al-Omari, 1991). Motivation is an indispensable thing in modern organizations because there is a big difference in an individual's performance when he is motivated by his performance and is not stimulated, and incentives are highly effective to facilitate the productive process. Objective and rational methods of motivation should be used as it leads to increased productivity and satisfying the needs of different individuals, thus achieving the objectives of the institution and exploiting the human effort fairly (Zoghbi and Obedah, 1997). The most common methods of evaluating performance is the reporting by the manager 
on the performance of the employee during a specified period, although there is a significant difference in the characteristics and specifications of these reports and methods used to measure the efficiency of workers as seen (Kubaisi, 2005).

Al-Harthy (1999), divided incentives in terms of its nature and value into: material incentives and moral incentives; material incentives must be of a financial, monetary or economic nature, which is considered one of the most important incentives that meet the needs of the individual and leads him to work loyalty and that include: remuneration, bonuses, periodic and special allowances and promotion (Hassan, 2002). One of the advantages of the material incentives include: The improvement of performance on a regular basis, increasing the speed and direct impact that the individual touches on his stress, and the inclusion of many psychological and social meanings (Abdel Wahab and Khatteb, 1993).

The most important foundations on which incentives are given after the evaluation process are: (Maher, 2010)

1. Performance: Is the excellence in performance, whether in quantity or quality. Performance is the most important criteria for the calculation of incentives.

2. Effort: The amount of effort exerted by the individual, although it is difficult to measure.

3. Progressivity: The period spent by the individual at work, this refers to loyalty and belonging to work.

4. Skill: The accreditation of qualifications, certificates and training courses as a basis for individual reward; this criterion is very limited and contributes little to the calculation of employee incentives.

The researcher believes that there is a clear consensus by researchers and writers interested in developing the work and the survival of the organization that respect must be given to the needs of the individual and linking the individual's goals of the development of the organization and attention to individual satisfaction and provide the best incentives to them.

\section{Research Problem}

Because of the importance of the role played by teachers in the success of the educational process and its direct impact on the level of the student and his abilities, this study was to be carried out to detect the degree of motivation and job satisfaction and the relationship between them through the sample of the intended teachers of public schools in Mafraq Governorate.

In light of the study problem, the study seeks to answer the following questions:

1. What is the degree of motivation of the teachers of public schools in the province of Mafraq Governorate from their point of view? 
2. What is the degree of job satisfaction among teachers of public schools in the province of Mafraq Governorate from their point of view?

3. Is there a statistically significant relationship between motivation and job satisfaction among teachers in government schools in Mafraq governorate?

\section{Research Objectives}

The study aimed to identify the degree of motivation and job satisfaction and the relationship between them from the point of view of the teachers of public schools in the Mafraq Governorate, and to identify the effect of independent variables such as gender, experience and school level in the degree of motivation and job satisfaction of teachers in public schools.

\section{Research Importance}

The importance of the study comes from the importance of its subject in the job satisfaction of teachers to determine the degree of job satisfaction among teachers of public schools in Mafraq Governorate. The researcher tried to identify the degree of motivation and satisfaction of teachers, and to identify the relationship between motivation and job satisfaction, as well as, determine the impact of some variables on job satisfaction as it is one of the most important things affecting the performance of the teacher in the performance of his duties to the fullest; the results of the study will be important for policymakers in the education sector, and the results will serve the Ministry of Education in developing development plans, school administrations, teachers and future researchers.

\section{The Study Sample}

The study Population consists of all teachers in the Directorate of Education of Governorate of Mafraq during the academic year 2015/2016 who are (2700) teachers, a (1400) questionnaire were distributed to teachers who were selected randomly of which (1272) questionnaires were collected, twelve (12) were found not valid for analysis, thus, 1260 were valid for analyses an average of $(90 \%)$ of the total questionnaires distributed; A $(46.6 \%)$ of the study population.

Descriptive statistics (frequency, percentages) were used to analyze the data using the Statistical Package for the Social Sciences (SPSS)

\section{Empirical Review}

There are many studies that recommended further research and investigation on the subject of job satisfaction and motivation of school teachers in view of the ongoing developments and changes in the educational sector. The most relevant empirical reviews are presented below. The 
researcher has divided studies related to the subject of motivation and job satisfaction into two sections:

1. Studies on Job Satisfaction.

2. Studies on Motivation.

\section{Studies on Job Satisfaction:}

Perrachione et al. (2008) conducted a study in Missouri to determine the internal and external variables affecting the satisfaction, retention of primary school teachers. The study sample consisted of (300) randomly chosen teachers the study showed that the internal incentives and the work environment significantly affect the degree of survival and retention in their work. The study sample (201) affected three internal stimuli in their survival and retention in their work, namely their effectiveness in teaching and the pleasure of working with students, and their job satisfaction. There were two external factors that had no effect on teachers' retention of their work using multiple linear regression and qualitative analysis, namely low salaries and overwork. The results show that teachers who suffered from satisfaction at school and satisfaction with the teaching profession were more likely to stay at work.

Peltzer (2008) conducted a survey aimed at revealing the relationship between self-employment stress and job satisfaction and the prevalence of stress-related diseases among teachers. The study population was composed of all public schools in South Africa. The study sample consisted of (21307) teachers of public schools. The results of the study showed that there is an increase in levels of tension among teachers. The study showed a relationship between work pressure and dissatisfaction with work, as well as most of the diseases related to the pressures of work are: high blood pressure, heart disease, stomach ulcers, mental disorders, and alcohol. The study showed that pressure on teaching methods and low peer support had an impact on high blood pressure and job insecurity.

Aldroubi (2006), conducted a survey aimed at identifying the relationship between job satisfaction and self-esteem, and revealing the level of job satisfaction and self-esteem among the principals of public schools in the northern governorates of Palestine. The study sample consisted of 302 managers; the study revealed that there is no relationship between the degree of job satisfaction and self-esteem among the principals and their principals in the northern governorates of Palestine.

Perie and Baker (1997) conducted a study aimed at identifying the role of certain factors related to job satisfaction such as school and workplace characteristics, teacher background, salaries and other benefits. The study sample consisted of (635) teacher in (80) schools using the Hoboken scale. The most important findings of the study are the strength of the correlation between 
teacher satisfaction and workplace conditions that are open to school policy changes.

Joghini (1994) conducted a study aimed at identifying the impact of material conditions, social status of teachers and job satisfaction in public schools in the Madaba district. The sample size of the study was (300) teachers and the study found that there is an effect of gender variable in relation to the material situation, social status and job satisfaction, and there was no effect of the variable of scientific qualification and achievement of job satisfaction.

\section{Studies on Motivation:}

Asiago et al. (2015) conducted a survey to explore the impact of nonfinancial incentives on job satisfaction among high school teachers at Casey schools in the Kenyan Republic. The study sample was randomly selected. The SPSS program was used to analyze the data. The study population consisted of (493) teachers. The study sample consisted of (83) teachers. The study revealed a positive relationship between non-financial incentives and job satisfaction among teachers. Non-financial incentives have been a comfortable working environment, setting up outstanding standards for promotion and including years of experience and regularity of work. The results of the study revealed a significant impact of non-financial incentives on job satisfaction among teachers.

Al-Akash (2007), the study aimed to identify the role of the incentives and rewards system and its impact on improving the performance of the Ministries of the Palestinian Authority in the Gaza Strip, through studying the system of government incentives and evaluating its effectiveness and its impact on performance. The most important results of the study were: the effectiveness of the system of incentives and rewards in improving the performance of employees in the Palestinian ministries in the Gaza Strip, the lack of controls and criteria for granting incentives, and there is no equity in the granting of incentives and bonuses, which adversely affected employees.

Toukan (1995), conducted a study aimed at identifying the attitudes of workers in public libraries towards the incentives of work and their impact on their performance and productivity in order to help develop appropriate solutions to develop the system of incentives for work to increase performance and productivity. The most important findings of the study: workers towards work incentives are negative because the incentives for the material work represented by the promotions, salaries and bonuses, and the moral incentives that are in the management practices of the head of work, which are in praise and appreciation, are below the minimum required. And that there is a relationship between job incentives and the degree of performance of workers for their work, where the level of performance of workers is low as with the level of incentives. 


\section{Comments on previous studies:}

In the light of previous relevant studies, it can be noted that most of the previous studies have focused on linking the subject of employee satisfaction with motivation, and have been discussed and measured in many aspects, in terms of the impact of material incentives on job satisfaction. There was also an interest in the management aspect and its role in the job satisfaction process.

\section{Data Statistical Analysis The Study Tool}

The researcher designed the questionnaire as a tool for collecting information after reviewing the theoretical literature on the subjects of motivation and job satisfaction, and reviewing the researches, studies and books that look at the relationship between motivation and job satisfaction. Thus, the study tool was composed of two parts in its initial form: Part 1: The teacher completed the questionnaire (gender, qualifications, and experience). Part II: It consisted of (50) paragraphs divided into two sub-parts: the first was the motivation, divided into two areas (stimulation, moral stimulation) include (23) paragraph. And the second: job satisfaction divided into two areas (satisfaction with salary, satisfaction with the nature of work) and included (27) paragraph.

\section{Reliability and Stability of the Study Tool}

The questionnaire was validated by presenting the study tool in its preliminary form to a group of arbitrators with expertise and specialization in educational and administrative affairs in the Jordanian universities. They were asked to express opinion in the sections of the study tool where the integrity of the wording of the paragraphs, and the extent of clarity of meaning in terms of language and the extent of the appropriate paragraphs of the field in which it was placed, either approval or modification of wording or deletion because of their importance. The researcher took the proposed amendments approved by (80\%) of the arbitrators, and the tool was issued in its final form of (45) paragraphs.

For the stability of the questionnaire, the consistency coefficient was calculated using the Cronbach's Alpha Test on a survey of 30 paragraph, with a time difference of three weeks, the stability coefficient was of 0,89 which is considered acceptable to conduct the study.

\begin{tabular}{|c|c|}
\hline \multicolumn{2}{|c|}{ Table 1 } \\
Reliability Statistics \\
\hline Cronbach's Alpha & N of Items \\
\hline 0.8918 & 30 \\
\hline
\end{tabular}




\section{The Correction Tool Actions}

These paragraphs were responded to by the five-dimensional Likert Scale, where it starts at grade (strongly agree) and is given (5) degrees, then (agree), and is given (4) degrees, then (undecided) which is given (3) degrees, then (disagree) and is given (2) degrees, and finally, with (strongly disagree) and is given only (1) degree. The researcher adopted a positive or negative indicator of the degree as follows:

The maximum limit for the alternatives of the study instrument is 5 , and the minimum of the alternatives is 1 , and by subtracting the minimum limit from the upper limit the score would be (4) degrees, and then dividing the difference between the two levels on three levels as shown in the following equation:

$4 \div 3$ levels (high, medium, low) $=1.33$ and so:

A. $\quad$ Minimum limit $($ low $)=1+1.33=2.33$

B. $\quad$ The average limit (medium) $=2.34+1.33=3.67$

C. Upper limit (high) $=3.68$ and above

Thus, the weights of paragraphs (3.68-5.0) are high, (2.34-3.67) medium, and (1.00- 2.33) low.

\section{Demographic Analysis}

Table 2 shows the demographic distribution of the sample.

\begin{tabular}{|c|c|c|c|}
\hline \multirow{3}{*}{ Distribution of the research sample according to the demographic variables } \\
\hline Variable & Statement & Frequency & Percentage \\
\hline \multirow{3}{*}{ Gender } & Male & 587 & $46.5 \%$ \\
\cline { 2 - 4 } & Female & 673 & $53.4 \%$ \\
\cline { 2 - 4 } & Total & 1260 & $100 \%$ \\
\hline Qualifications & Diploma & 37 & $2.9 \%$ \\
\cline { 2 - 4 } & Bachelor & 864 & $70.9 \%$ \\
\cline { 2 - 4 } & Higher Studies & 359 & $28.4 \%$ \\
\cline { 2 - 4 } & Total & 1260 & $100 \%$ \\
\hline \multirow{2}{*}{ Experience } & Less than 5 years & 343 & $27.2 \%$ \\
\cline { 2 - 4 } & $5-10$ years & 497 & $39.4 \%$ \\
\cline { 2 - 4 } & More than 10 years & 420 & $33.3 \%$ \\
\cline { 2 - 4 } & & 1260 & $100 \%$ \\
\hline Total & & & \\
\hline
\end{tabular}

Table 2 shows that there is (46.5\%) males and (53.4\%) females; $(2.9 \%)$ with Diploma degrees, (70.9\%) with Bachelor degrees, and $(28.4 \%)$ with higher degrees of studies; (27.2\%) have less than 5 years of experience, (39.4\%) from 5-10 years of experience, and (33.3\%) with more than 10 years of experience. 


\section{Statistical Analysis}

The study aimed is to detect the relationship between motivation and job satisfaction among school teachers in Mafraq Province of Jordan, as well as the nature of the relationship between them in the light of personal variables, by answering each of the following study questions:

Firstly: the results related to the first question: What is the degree of motivation of the teachers of public schools in the province of Mafraq Governorate from their point of view? To answer this question, the arithmetical averages and the standard deviations of the responses of the sample of the study sample were extracted from the areas of motivation as seen in table 3 .

\begin{tabular}{|} 
The arithmetical means and standard deviations of the sample responses \\
on the areas of motivation are arranged in descending order according to \\
the arithmetic mean.
\end{tabular}

Table 3 shows that, the field of motivation came first with an average of 2.97, while moral motivation came with an average of (2.47). The table also shows that, the degree of motivation from the point of view of public school teachers in Mafraq governorate was medium with an average of 2.72. The researcher attributed this to the absence of material incentives and bonuses, the absence of the use of an objective incentive system, the lack of involvement of the teacher in decision-making and the lack of an objective incentive system to distinguish outstanding performance. This is in line with the study of Al-Akash (2007), that there are no rules and criteria for granting incentives, and there is no fairness in granting incentives and rewards, which has adversely affected staff.

The arithmetical means and standard deviations of the sub-paragraphs regarding motivation were also extracted as seen in table 4 .

\begin{tabular}{|c|c|c|c|c|c|c|}
\hline \multicolumn{7}{|c|}{$\begin{array}{c}\text { Table } 4 \\
\text { Arithmetical Means and Standard Deviations of Physiological Field of Motivation } \\
\text { Paragraphs }\end{array}$} \\
\hline Rank & $\begin{array}{c}\text { Paragraph } \\
\text { Number }\end{array}$ & Paragraph & \multicolumn{2}{|c|}{ Arithmetical Mean } & $\begin{array}{l}\text { Standard } \\
\text { Deviation }\end{array}$ & $\begin{array}{c}\text { Degree of } \\
\text { assessment }\end{array}$ \\
\hline \multicolumn{7}{|c|}{ Motivation } \\
\hline 1 & 7 & \multicolumn{2}{|c|}{$\begin{array}{l}\text { The school encourages us to } \\
\text { establish a relationship of love and } \\
\text { mutual respect between colleagues } \\
\text { at work. }\end{array}$} & 3.43 & 1.44 & Medium \\
\hline
\end{tabular}




\begin{tabular}{|c|c|c|c|c|c|}
\hline 2 & 6 & $\begin{array}{l}\text { The school motivates us to create } \\
\text { opportunities to acquire new skills } \\
\text { and experiences }\end{array}$ & 3.33 & 1.28 & Medium \\
\hline 3 & 1 & $\begin{array}{l}\text { The school motivates us to work in a } \\
\text { team spirit. }\end{array}$ & 3.09 & 1.07 & Medium \\
\hline 4 & 5 & $\begin{array}{l}\text { The school encourages us to develop } \\
\text { social relationships with teachers } \\
\text { both inside and outside the school. }\end{array}$ & 3.06 & 1.07 & Medium \\
\hline 5 & 4 & $\begin{array}{c}\text { The school encourages us to } \\
\text { participate in training courses related } \\
\text { to professional development }\end{array}$ & 2.99 & 1.19 & Medium \\
\hline 6 & 3 & $\begin{array}{c}\text { The school motivates my fellow } \\
\text { teachers to share their social } \\
\text { opportunities }\end{array}$ & 2.93 & 0.61 & Medium \\
\hline 7 & 9 & $\begin{array}{l}\text { The school encourages us to } \\
\text { maintain a relationship based on } \\
\text { understanding and harmony with } \\
\text { colleagues }\end{array}$ & 2.93 & 0.91 & Medium \\
\hline 8 & 2 & $\begin{array}{l}\text { The school motivates us to develop } \\
\text { performance to obtain the necessary } \\
\text { promotion and financial rewards }\end{array}$ & 2.63 & 0.92 & Medium \\
\hline 9 & 8 & $\begin{array}{l}\text { The school is motivated to conduct } \\
\text { educational research }\end{array}$ & 2.32 & 0.92 & Low \\
\hline \multicolumn{3}{|r|}{ The Field as a whole } & 2.97 & 0.87 & Medium \\
\hline \multicolumn{6}{|c|}{$\begin{array}{l}\text { Moral Motivation } \\
\end{array}$} \\
\hline 10 & 12 & $\begin{array}{c}\text { The school always distributes } \\
\text { certificates of thanks and } \\
\text { appreciation }\end{array}$ & 2.69 & 0.61 & Medium \\
\hline 11 & 10 & $\begin{array}{l}\text { The school offers an honor plate } \\
\text { with special decorations to honor }\end{array}$ & 2.65 & 0.76 & Medium \\
\hline 12 & 11 & $\begin{array}{l}\text { I receive thank-you letters when I } \\
\text { take care of my work }\end{array}$ & 2.37 & 0.77 & Medium \\
\hline 13 & 13 & $\begin{array}{l}\text { I receive support and support when } \\
\text { exposed to special circumstances }\end{array}$ & 2.35 & 0.74 & Medium \\
\hline 14 & 14 & $\begin{array}{l}\text { I receive appreciation of my } \\
\text { managers when I develop the work } \\
\text { performance }\end{array}$ & 2.30 & 0.69 & Low \\
\hline \multicolumn{3}{|r|}{ The Field as a whole } & 2.47 & 0.91 & Medium \\
\hline
\end{tabular}

Table 4 above shows that, the arithmetical means of the responses of the individuals in the study sample on the subjects of the field of motivation ranged from (2.32) as in paragraph (8): "the school is motivated to conduct educational research" and (3.43) as in paragraph (7): "The school encourages us to establish a relationship of love and mutual respect between colleagues at work". With an average of (2.97) to the filed as a whole. This is because the administration in the school always tries to have internal good relationships between teachers and tries to reduce conflicts between teachers to focus on their teaching performance. The administration gives teachers limited room to 
participate in some internal decisions such as teaching schedule, schedule of daily shifts, and planning of some activities; but this room of participation is limited and monitored by the administration and the final decision is due to the vision of management so their response was medium. Due to the limited time, the teachers devote their efforts to finishing the school curriculum, and due to the poor budget, research does not receive any interest from the administration, and there is no material or moral incentives to encourage teachers to conduct scientific research. The table also shows that, the arithmetical means of the responses of the sample on the subjects in the field of moral motivation ranged from (2.30) as in paragraph (14): "I receive appreciation of my managers when I develop the work performance" and (2.69) as in paragraph (12) " The school always distributes certificates of thanks and appreciation" With an average of (2.47) to the filed as a whole.

The researcher attributed this to the fact that the school administration distributes certificates of thanks and appreciation to the teachers in the few school events and celebrations, and there are no special occasions for the distribution of certificates of appreciation and thanks and distinguishing the outstanding performance of teachers due to the absence of monitoring and encouragement system. To identify the degree of skill of the Director of the organization in the use of incentives of both material and moral to improve the level of performance of employees and to identify the standard used by the manager in assessing the performance of employees to motivate them, and found that the manager has good skill in stimulating and has the for the strong impact of incentives used to improve performance.

Secondly: Results related to the second question: What is the degree of job satisfaction among teachers of public schools in the province of Mafraq Governorate from their point of view? To answer this question, the arithmetical means and the standard deviations of the sample responses were extracted from the field of job satisfaction as seen in table 5 .

\begin{tabular}{|c|c|c|c|c|c|}
\hline \multicolumn{6}{|c|}{$\begin{array}{l}\text { Table } 5 \\
\text { The statistical averages and the standard deviations of the responses of the sample of the study } \\
\text { sample on the areas of job satisfaction }\end{array}$} \\
\hline $\mathbf{N}$ & Rank & Field & Arithmetical Mean & $\begin{array}{l}\text { Standard } \\
\text { Deviation }\end{array}$ & $\begin{array}{c}\text { Assessment } \\
\text { Degree }\end{array}$ \\
\hline 1 & 2 & $\begin{array}{l}\text { Satisfaction with } \\
\text { salary }\end{array}$ & 2.99 & 0.83 & Medium \\
\hline 2 & 1 & $\begin{array}{l}\text { Satisfaction with } \\
\text { the nature of work }\end{array}$ & 3.42 & 0.69 & Medium \\
\hline \multicolumn{3}{|c|}{ The Tool as a Whole } & 3.21 & 0.76 & Medium \\
\hline
\end{tabular}

The field of satisfaction with the nature of work came in first place with an average of (3.42), while the field of satisfaction with the salary came in the second place, with an average of (2.99). The table also shows that the degree of job satisfaction among school teachers in Mafraq governorate from their 
point of view was with a mean of (3.21) which is a medium degree. The researcher is satisfied that the sense of job security due to work in a government sector provides a stable income and is commensurate with the basic requirements of living and health insurance and a respected social status among members of society.

The arithmetical means and standard deviations of the sub-paragraphs regarding job satisfaction were also extracted as seen in table 6 .

\begin{tabular}{|c|c|c|c|c|c|}
\hline \multicolumn{6}{|c|}{$\begin{array}{c}\text { Table } 6 \\
\text { Arithmetical means and standard deviations of mental field paragraphs }\end{array}$} \\
\hline Rank & $\begin{array}{c}\text { Paragraph } \\
\text { number }\end{array}$ & Paragraph & $\begin{array}{l}\text { Arithmetical } \\
\text { Mean }\end{array}$ & $\begin{array}{l}\text { Standard } \\
\text { Deviation }\end{array}$ & $\begin{array}{l}\text { Degree of } \\
\text { assessment }\end{array}$ \\
\hline \multicolumn{6}{|c|}{ Salary Satisfaction } \\
\hline 1 & 3 & $\begin{array}{l}\text { I am satisfied with the bonuses and } \\
\text { annual increases added to my } \\
\text { salary. }\end{array}$ & 3.51 & 1.50 & Medium \\
\hline 2 & 7 & $\begin{array}{l}\text { My salary is commensurate with } \\
\text { the amount of work am assigned } \\
\text { with }\end{array}$ & 3.50 & 1.32 & Medium \\
\hline 3 & 4 & $\begin{array}{l}\text { My salary is appropriate compared } \\
\text { to the rest of my colleagues }\end{array}$ & 3.45 & 1.32 & Medium \\
\hline 4 & 5 & $\begin{array}{l}\text { The penal system is applied by } \\
\text { deduction of salary }\end{array}$ & 3.20 & 1.46 & Medium \\
\hline 5 & 6 & $\begin{array}{l}\text { I have to do extra work to cover } \\
\text { the cost of living }\end{array}$ & 3.00 & 1.42 & Medium \\
\hline 6 & 8 & $\begin{array}{l}\text { My salary is commensurate with } \\
\text { the living requirements }\end{array}$ & 2.52 & 1.33 & Medium \\
\hline 7 & 1 & $\begin{array}{l}\text { I see that the system of salaries and } \\
\text { benefits is fair }\end{array}$ & 2.37 & 1.05 & Medium \\
\hline 8 & 2 & $\begin{array}{c}\text { There are rewards for salary based } \\
\text { on performance and activity }\end{array}$ & 2.35 & 1.51 & Medium \\
\hline \multicolumn{3}{|c|}{ The Field as a whole } & 2.99 & 0.99 & Medium \\
\hline \multicolumn{6}{|c|}{ Satisfaction with the nature of work } \\
\hline 9 & 10 & I feel secure in my job & 3.63 & 1.05 & Medium \\
\hline 10 & 14 & $\begin{array}{l}\text { Laws that safeguard the rights of } \\
\text { the teacher are applied during work }\end{array}$ & 3.61 & 0.97 & Medium \\
\hline 11 & 11 & $\begin{array}{l}\text { I am happy and proud to have the } \\
\text { opportunity to work in a public } \\
\text { sector school }\end{array}$ & 3.55 & 0.89 & Medium \\
\hline 12 & 12 & $\begin{array}{l}\text { The tasks and responsibilities } \\
\text { required from me are clear and } \\
\text { appropriate }\end{array}$ & 3.42 & 0.99 & Medium \\
\hline 13 & 13 & My job provides creativity at work & 3.33 & 1.16 & Medium \\
\hline 14 & 15 & $\begin{array}{l}\text { I can achieve myself through my } \\
\text { work }\end{array}$ & 3.22 & 1.55 & Medium \\
\hline 15 & 9 & $\begin{array}{c}\text { Through my job I achieve a good } \\
\text { social status }\end{array}$ & 3.17 & 1.44 & Medium \\
\hline \multicolumn{3}{|c|}{ The Field as a whole } & 3.42 & 1.18 & Medium \\
\hline
\end{tabular}


Table 6 above shows that, the arithmetical means of the responses of the individuals in the study sample to the subjects of the field of salary satisfaction ranged from (2.35) as in paragraph (2): "There are rewards for salary based on performance and activity", and (3.51) as in paragraph (3): " I am satisfied with the bonuses and annual increases added to my salary". With an average of (2.99) to the filed as a whole, this is a medium score. The researcher attributed that there are bonuses and annual increases for all categories of workers in the education sector, regardless of the level of performance during the academic year, but vary according to the degree of employment of the employee. There are few and rare rewards to support excellence in performance, such as the Queen Rania Award for Distinguished Teacher and the Ideal Employee Award at the level of workers in the education sector in Jordan.

The table also shows that the mathematical means of the responses of the sample to the subjects in the field of satisfaction with the nature of the work, ranged from (3.17) as in paragraph (9): "Through my job I achieve a good social status" and (3.63) as in paragraph (10) "I feel secure in my job", with an average of (3.42) to the filed as a whole, which is a medium score. The researcher attributed this to the fact that working with the government sector is not subject to any individual or personal threat or arbitrary decisions leading to loss of the job, where there are many laws and regulations governing the work of the employee of the Ministry of Education. The profession of education is a good place for its employees compared to the rest of the professions in the society because it achieves an acceptable standard of living, and cultural level respect, and the availability of laws, regulations and instructions that governing the work of teachers which earns it a high position on the ladder of other jobs

Thirdly: Results related to the third question: Is there a statistically significant relationship between motivation and job satisfaction among teachers in government schools in Mafraq Governorate?

To answer this question, Pearson Correlation coefficients were extracted at the level of significance $(\alpha=0.05)$ between the degree of motivation and job satisfaction as seen Table 7 .

\begin{tabular}{|c|c|c|}
\hline \multicolumn{3}{|c|}{$\begin{array}{c}\text { Table } 7 \\
\text { Pearson correlation coefficient and the statistical significance of the relationship } \\
\text { between the degree of motivation and job satisfaction among teachers in Mafraq } \\
\text { Governorate }\end{array}$} \\
\hline Total respondents & Coefficient of correlation & Level of significance \\
\hline 1260 & 0.11 & 0.02 \\
\hline
\end{tabular}

Significance $(\alpha=0.05)$

The table above Indicates that, there is a statistically significant relationship between the degree of motivation and job satisfaction among teachers in Mafraq governorate, which means that, whenever there is 
motivation there is satisfaction with the job; the researcher attributed for employees to feel satisfied, a variety of incentives - material or moral - must be offered by the administration, to ensure that their work is being followed up and evaluation of their performance and efforts are appreciated. Incentives are the driving force of the workers' activity, so the individual feels the excellence of his performance and always tries to develop from himself. This was agreed with the study of Toukan (1995), which showed that there is a relationship between the incentives for work and the degree of performance of workers for their work as the level of performance of workers is low as with the level of incentives.

\section{CONCLUSION AND RECOMMENDATIONS Summary of Findings and Conclusion}

In view of the ongoing developments and changes in the educational sector, and the great role played by the teachers in the development of the educational process - where the teacher is the cornerstone of this process - it is necessary to provide material and non-material incentives to the teacher so that he can perform his mission to the fullest and thus, bring out capable generations to improve their homeland.

The research shows that, the degree of motivation among teachers of public schools in Mafraq Province is medium, as well as the degree of job satisfaction; and the research also showed that there is a statistically significant relationship between motivation and job satisfaction among teachers. The study showed that there is a lack of material incentives and bonuses, lack of a clear system of motivation that really measure the performance of the teachers, and lack of involvement of the teacher in decision-making; as well as the lack of controls and criteria for the granting of incentives and the absence of equity in the granting of incentives and rewards, and thus, on the educational process as a whole. This is consistent with many previous studies.

\section{Recommendations}

The study concluded with a set of recommendations that educational officials should consider in order to achieve a high and distinguished performance among the employees by working on the development of the laws, regulations and instructions of the system of bonuses and rewards commensurate with the requirements of the basic standard of living of the employees. The performance of the teachers union to play a greater role in protecting teachers and securing their future. The study recommends further studies on the level of job satisfaction of teachers and the factors affecting it based on developments and developments in life and work. 


\section{Acknowledgments}

The researcher would like to extend her sincere thanks and gratitude to the editors and reviewers for their valuable comments and suggestions to complete this research.

\section{References:}

1. Abdel Wahab, A. M. and Khatteb A. S. (1993). Personnel Affairs and Human Relations. Ain Shams Library, Cairo.

2. Alabiad, A. M. (2015). Satisfaction of academic career in the light of academic specialization and grade in a sample of students of teachers college in Saudi Arabia. Journal of Educational Research. Al-Azhar University. $\mathrm{N}^{\mathrm{o}}$ (128) pp. 125:194) .

3. Aldroubi, Suleiman. (2006). Motivation by self-awareness. $1^{\text {st }}$ Edition. Dar Alam culture for publishing and distribution. Amman Jordan.

4. Al-Akash, A. (2007). The System of Incentives and Remuneration and its Impact on Improving Functionality in the Ministries of the Palestinian Authority. Unpublished Master Thesis. Islamic University, Gaza, Palestine.

5. Al-Harthy, D. A. (1999). Raising the efficiency of employees and their relation to material and moral incentives. Unpublished Master Thesis, Naif Arab Academy for Security Sciences, Riyadh

6. Al-Omari, K. (1991). Job Satisfaction of Educational Supervisors in Jordan and Its Relation to Some Demographic and Functional Variables of the Supervisor. Published Master Thesis, Yarmouk University, Jordan. Yarmouk Research Journal. Vol. 7, No. 150.

7. Asiago Lenah Sabina and others (2015). Effect of Non-Financial Incentives on Job Satisfaction of Teachers in Public Secondary Schools-Survey of Kisi Sub County. Journal of Education and Practice. Vol.6, No.13.

8. Awadallah, M. T. (2011). The Effect of Motivation and its Role in Achieving Job Satisfaction for Employees, MBA Program. The Arab Academy of Denmark.

9. Beverly A. Perrachione \& others (2008). Why Do They Stay? Elementary Teachers' Perceptions of Job Satisfaction and Retention. Professional Educator. Vol. 32, No. 2.

10. Hassan, I. B. (2002). Human Resources Management from a Strategic Perspective, Dar al-Nahda al-Arabiya, Beirut, Lebanon.

11. Hamdi, M. A. (2011). Job Satisfaction Head of the Development of Educational Work. Jazan Educational Newspaper. http://jep.gov.sa

12. Joghini, Naeem (1994). Physical conditions, social status of the teacher and satisfaction with the profession in public schools in the district of 
Madaba. Journal of Humanities Studies. Vol. 22 (1), No. 5. pp. $2137-$ 2166.

13. Kubaisi, A. K. (2005). Human Resources Management in the Civil Service. Arab Organization for Administrative Development. Cairo.

14. Maher, Ahmad (2010). Wages and Compensation Systems. University House. Alexandria, Egypt.

15. Maqbol, R. W. (2003). The Degree of Job Satisfaction with the Teachers and Mentors of Public Schools in the Directorate of Education in the West Bank Governorates. Unpublished Master Thesis. Al-Najah National University. Palestine.

16. Peltzer, Ketal (2008). Job stress, Job satisfaction and stress, African educators. Stress Medicine Journal. Vol. 25, No. 3, pp 247-257.

17. Perie, Marianne and Baker, David (1997). Job Satisfaction Among America's Teachers: Effects of Workplace Conditions, Background Characteristics, and Teacher Compensation. U.S. Department of Education, Office of Educational Research and Improvement NCES 97-XXX.

18. Raslan, Nabeel (1978). Incentives in the law of employees of the government and the public sector. Dar al-Nahda al-Arabiya. Cairo, Egypt

19. Toukan, Ali (1995). Attitudes of Public Library Workers in Palestine towards Work Incentives and their Effect on Performance Efficiency. Library Letter. Vol. 32, No. 4.

20. Youssef, Mona (1997). Satisfaction with the work of graduates of the department of home economics who work in their specialty and who work in teaching other materials in the State of Qatar. The Yearbook of the Faculty of Education (14). Qatar

21. Zoghbi, F., Abedah, M. I., (1997). The basics of modern management. $1^{\text {st }}$ Edition. Future House. Amman, Jordan. 